\title{
Sıfır Atık Kapsamında Atık Elektrikli ve Elektronik Eşyaların Geri Kazanımı: Halkın Bu Konudaki Tutumu
}

\author{
Esra AY SARIYAR ${ }^{1}$, Sevde ÜSTÜN ODABAŞI ${ }^{2 *}$, Hanife BÜYÜKGÜNGÖR ${ }^{3}$
}

\begin{abstract}
$\ddot{\mathbf{O z}}$
Gelişen teknolojiye paralel olarak artan elektrikli ve elektronik eşya tüketimi son yıllarda büyük bir problem oluşturmaktadır. Atık elektrikli ve elektronik eşyalar (AEEE), zararlı ve tehlikeli materyaller içermesi nedeni ile çevreyi tehdit ederken aynı zamanda değerli ve geri dönüştürülebilir materyaller içermesi nedeni ile de ekonomik açıdan önemli bir yere sahiptirler. Sıfır atık kapsamında bir AEEE yönetimi yapabilmek için kişilerin e-atık oluşturma potansiyellerinin bilinmesi gerekmektedir. Bu çalışmada, elektrikli ve elektronik cihazların geri kazanılmasının çevresel, yasal ve ekonomik boyutları ele alınmış ve Samsun ili merkezinde yapılan bir anket araştırması ile mahalle sakinlerinin elektrikli ve elektronik eşya tüketim eğilimi ve atık bilinci tespit edilmek istenmiştir. Samsun ili İlkadım ilçesine bağlı Bahçelievler Mahallesi pilot bölge seçilerek 100 kişiyi kapsayan bir anket çalışması yapılmıştır. Kişilerin elektrikli ve elektronik ürün kullanımı ve değiştirme davranışları, AEEE hakkındaki bilgileri ve bertaraf yöntemleri araştırılmıştır. Çalışmada, katılımcıların \%62'si yaşadıkları çevrede AEEE toplama kutularına rastlamadıklarını ve \%79'u yaşadıkları çevrede AEEE toplama kutularının bulunması durumunda atıklarını bu kutulara atacaklarını belirtmiştir. Ayrıca çalışmada katılımcıların \%41'i pilleri e-atık olarak nitelendirmiştir. Yine katılımcıların \%29'u e-atıkların hiçbir farklı işlem uygulamadan günlük çöplerle birlikte toplandığını ifade etmişlerdir. Anket sonuçlarına göre, katılımcılar e-atıkların farkındadır, ancak e-atıkların içeriği ve bertarafı konusunda bilgilendirilmeleri ve e-atıklarını mevzuata uygun bir şekilde atmaları konusunda daha fazla motive edilmesi gerektiği düşünülmektedir.
\end{abstract}

Anahtar Kelimeler: AEEE, E-Atık, Geri Dönüşüm, Geri Kazanım, Sıfır Atık.

\section{Recovery of Waste Electrical and Electronic Equipment within the Scope of Zero Waste: The Attitude of the People on This Issue}

\begin{abstract}
The consumption of electrical and electronic equipment, which has increased in parallel with the developing technology, has been a major problem in recent years. Waste electrical and electronic equipment (WEEE) threatens the environment as it contains harmful and hazardous materials, while at the same time it has an important place economically because it contains valuable and recyclable materials. In order to make AEEE management within the scope of zero waste, it is necessary to know the e-waste generation potential of the people. In this study, the environmental, legal and economic dimensions of the recycling of electrical and electronic devices were discussed and it was aimed to determine the electrical and electronic equipment consumption tendency and waste awareness of the residents of the neighborhood with a survey study conducted in the city center of Samsun. Bahçelievler Neighborhood of Samsun province's İlkadım district was selected as a pilot area and a survey study covering 100 people was conducted. People's use and changing behaviors of electrical and electronic products, their knowledge about WEEE and disposal methods were investigated. In the study, $62 \%$ of the participants stated that they did not find WEEE collection boxes in their environment and $79 \%$ of them would throw their waste into these boxes if there are WEEE collection boxes in their environment. In addition, $41 \%$ of the participants in the study described batteries as e-waste. Again, $29 \%$ of the participants stated that e-wastes are collected together with daily garbage without applying any different processes. According to the results of the survey, the participants are aware of e-waste, but it is thought that they should be informed about the content and disposal of e-waste and should be more motivated to dispose of their e-waste in accordance with the legislation.
\end{abstract}

Keywords: WEEE, E-Waste, Recycling, Recovery, Zero Waste.

${ }^{1}$ TCDD Genel Müdürlüğü Etüt Proje Dairesi Başkanlığı Gar, Ankara, Türkiye, esraay_@ @hotmail.com

${ }^{2}$ Ondokuz Mayıs Üniversitesi, Mühendislik Fakültesi, Çevre Mühendisliği Bölümü, Samsun, Türkiye, sevde.ustun@omu.edu.tr

${ }^{3}$ Ondokuz Mayıs Üniversitesi, Mühendislik Fakültesi, Çevre Mühendisliği Bölümü, Samsun, Türkiye, hbuyukg@omu.edu.tr

${ }^{1}$ https://orcid.org/0000-0003-0150-2048 ${ }^{2}$ https://orcid.org/0000-0003-3533-4089 ${ }^{3}$ https://orcid.org/0000-0003-1201-6862 


\section{Giriş}

Bilgi toplumu olma yönünde dünya hızlı adımlarla ilerlerken, elektrikli ve elektronik cihazların kullanım ömürleri her geçen gün azalmaya başlamıştır. Satın alınan her elektronik ürün kısa bir süre sonra popülerliğini yitirip tozlu raflarda yerini yenisine bırakmaktadır. Bunun sonucunda çevreye bırakılan atık elektrikli ve elektronik eşya (AEEE veya e-atık) kirliliğinin nicel ve nitel olarak artması, çevrenin kendisini yenileyebilme yeteneğinin çok üzerine çıkmış ve çevre hızla tahrip olmaya başlamıştır (Keleş ve ark., 2015). Bu nedenle sürdürülebilir kalkınma ve onu takiben sıfır atık çerçevesinde AEEE'lerin geri dönüşümü önem kazanmıştır.

Bilgi ve teknoloji çağının istenmeyen bir sonucu olan bu yeni atık türü e-atık olarak adlandırılmaktadır (Dwivedy ve Mittal, 2010). AEEE’lerin yönetiminde karşılaşılan en önemli sorun atıkların artan miktarı değildir. AEEE'lerin içerdikleri tehlikeli organik ve inorganik maddeler, eatıkların evsel atıklarla birlikte atılmasını mümkün kılmamaktadır. Elektrikli ve elektronik eşyaların (EEE) uygun bir biçimde toplanmadığı, geri kazanılmadığı, geri dönüştürülmediği ya da bertaraf edilmediği takdirde içerdikleri zararlı maddeler çevreye kontrolsüz bir biçimde yayılarak geri döndürülemez tahribatlara neden olmaktadır. AEEE'lerin sahip olduğu civa, kadminyum gibi ağır metaller, klorlu ve bromlu maddeler, mineral yağlar gibi zararlı maddeler sadece deponilerdeki toprak kirliliğine değil, yağışlarla yüzey ve yeraltı sularının da kirlenmesine neden olacaktır (Widmer ve ark., 2005; Gullet ve ark., 2007). EEE'ler çoğunluğu zehirli olan 1000'den fazla madde içermektedir. İçerdikleri klorür ve bromür bileşikleri nedeniyle, atık olarak yakıldıkları zaman çevreye insanlar için zararlı olan dioksin ve furan açığa çıkmaktadır (Şentürk, 2019). AEEE'lerin içerisinde bulunan kurşun, suya ve toprağa karışan en zararlı ağır metal olarak bilinmektedir. Kurşun, sinir sistemi, beyin gelişimi, böbrekleri etkilemektedir. Li ve ark., (2006) anakart, ses kartı, işlemci gibi bilgisayar parçalarının atıklarından çevreye salınan kurşun konsantrasyonları, bir atığı tehlikeli olarak sınıflandırmak için yönetmelikteki limit değer olan 5 mg/L’nin 30-100 katı olan 150 ila 500 mg/L arasında değiştiğini gözlemlemişlerdir. Çevreye zararlı bir diğer ağır metal ise civadır. Civa, alkalin pillerde, tıbbi cihazların içerisinde, düz ekran monitörlerdeki (LCD) floresan lambalarda ve cep telefonlarının içerisinde kullanılmaktadır. Civa insanların beyin ve böbreklerinde ciddi hasarlara neden olmaktadır (REC, 2016). Tablo 1 'de AEEE'lerin içerisinde bulunan başlıca tehlikeli bileşenler verilmiştir. $\mathrm{Bu}$ atıklar çevreye ve insan sağlığına uygun doğru tekniklerle ayrıştırılıp geri kazanıldığında çevreye etkisi olmamaktadır. Ancak çevreye uygun olmayan ve güvenlik önlemleri yetersiz yöntemlerle yapılan işlemlerde, bu zararlı maddeler toprağa, suya ve havaya karışmakta doğal kaynakları kirletme riski oluşturmaktadırlar.

AEEE'lerin geri dönüşümü ve geri kazanımı, bu atıkların içerdikleri bakır, platin, altın, gümüş gibi değerli materyallerin kazanılması bakımından oldukça önemlidir (Ay ve Büyükgüngör, 2011). 
AEEE’lerin geri kazanımı ve geri dönüşümü çevreye yarar sağlamasının dışında ekonomiye de büyük katkı sağlamaktadır. Dünyada bir yılda oluşan AEEE'lerin içerdikleri altın miktarı yaklaşık 300 ton civarındadır. Bu miktar madenlerde üretilen altın miktarının yaklaşık \%11'ine tekabül etmektedir (REC, 2016; URL-1). Çevresel açıdan, geri dönüşüm faaliyetlerinin en kötüsü bile en faydalı madencilik faaliyetinden daha az zararlıdır. AEEE'lerin geri dönüşümü sırasında metal elde edilmesi sırasında harcanan enerji cevherden metal elde edilmesi sırasında kullanılan enerji miktarından düşüktür. Bu nedenle önemli miktarda enerji tasarrufu sağlanmış olur (Şentürk, 2019). 1 kg'lık alüminyumun geri dönüştürülmesi ile $8 \mathrm{~kg}$ boksit cevheri, $4 \mathrm{~kg}$ kimyasal madde ve $14 \mathrm{kw}$ saat elektrik enerjisi tasarrufu sağlanmaktadır. Benzer şekilde bakırın geri dönüşümünde madencilik faaliyetine göre kullanılan enerji, toplam enerjinin sadece \%13'ünü oluşturmaktadır (Çelik, 2007). Sonuçta geri dönüşüm ve geri kazanım faaliyetleri ile elde edilen metaller, madencilik faaliyetleri için gereken zaman ve maliyeti düşürerek hem ekonomik fayda sağlamakta hem de çevre ve insan sağlığına olan zararlı etkileri en aza indirmektedir (REC, 2016).

Tablo 1. AEEE'lerin içerisinde yer alan tehlikeli bileşenler (Çelik, 2007; Lambert ve Gupta, 2005).

\begin{tabular}{cc}
\hline Materyaller & Uygulama \\
\hline Ă̆ır Metaller & \\
$\mathrm{Cd}, \mathrm{Ni}, \mathrm{Zn}, \mathrm{Pb}, \mathrm{Hg}$ & Piller, floresan tüpleri \\
$\mathrm{Sn}, \mathrm{Pb}, \mathrm{Cd}$ & Lehim \\
$\mathrm{Ba}, \mathrm{Sr}, \mathrm{Pb}$ & Katot Işıııı tüpü camları \\
$\mathrm{Cd}, \mathrm{Y}, \mathrm{Eu}, \mathrm{Se}, \mathrm{Zn}$ & Floresan tozları \\
$\mathrm{Hg}$ & Röleler \\
\hline Yarı İetkenler & \\
$\mathrm{B}, \mathrm{Ga}, \mathrm{In}, \mathrm{As}$ & Bileşik Devreler \\
$\mathrm{Ga}, \mathrm{As}$ & LED, fotovoltaik hücreler \\
$\mathrm{Se}, \mathrm{Ge}$ & Diyotlar \\
$\mathrm{Se}$ & Fotokopi Tamburları \\
\hline Organik Bileşenler & \\
$\mathrm{PCB}$ & Kondansatörler \\
\hline Plastik Katkıları & \\
$\mathrm{Cl}$ & PVC \\
$\mathrm{Cd}, \mathrm{Pb}, \mathrm{Ni}, \mathrm{Ti}, \mathrm{Sb}$ & Pigmentler \\
$\mathrm{Pb}, \mathrm{Ba}, \mathrm{Cd}, \mathrm{Sn}$ & Stabilizatörler \\
\hline
\end{tabular}

Avrupa Birliği (AB) e-atıkların sürdürülebilir yönetimini sağlamak amacıyla “Atık Elektrikli ve Elektronik Eşyalar (AEEE) Direktifi ve Elektrikli ve Elektronik Eşyalarda Bazı Zararlı Maddelerin Kullanımının Sınırlandırılması (RoHS) Direktifini” yayınlamıştır (Anonim, 2011). Ülkemizde ise Çevre ve Şehircilik Bakanlığı, Avrupa birliğindeki bu direktifleri ulusal mevzuata uyumlaştırarak, AEEE yönetimini düzenlemek için 2012 yılında “Atık Elektrikli ve Elektronik Eşyaların Kontrolü Yönetmeliği’ni yayınlamıştır. Atık Elektrikli ve Elektronik Eşyaların Kontrolü Yönetmeliği (Tarih 22.05.2012 R.G. sayı 28300) kapsamında EEE atıkları; büyük ev eşyaları, küçük ev aletleri, bilişim ve telekomünikasyon ekipmanları, tüketici ekipmanları, aydınlatma ekipmanları, elektrikli ve 
elektronik aletler (büyük ve sabit sanayi aletleri hariç olmak üzere), oyuncaklar, eğlence ve spor ekipmanları, tıbbi cihazlar, izleme ve kontrol aletleri, otomatlar olarak kategorize edilmiş ve bu kategorilerde ayrıntılı bir liste olarak açıklanmıştır (Anonim, 2012). Bu kapsamda, AEEE'lerin tekrar kullanımı, geri kazanımı ve geri dönüşümü desteklenmektedir. Bu süreç doğrultusunda ilgili paydaşların görev ve sorumlulukları tanımlanarak verimliliğin arttırılması hedeflenmektedir (McMahon ve ark., 2019).

Ayrıca ülkemizde sıfır atık kapsamında AEEE'lerin miktarlarının azaltılması, yeniden kullanımı, geri kazanımı ve geri dönüşümü önemli bir yer kaplamaktadır. Sıfır atık; israfın önlenmesini, kaynakların daha verimli kullanılmasını, atık oluşum sebeplerinin gözden geçirilerek atık oluşumunun engellenmesi veya minimize edilmesi, atığın oluşması durumunda ise kaynağında ayrı toplanması ve geri kazanımının sağlanmasını kapsayan atık yönetim felsefesidir (Anonim, 2019a). Sıfır atık yönetmeliği Madde 14 (2)'de; “Atık pil, bitkisel yăg, atık elektrikli ve elektronik eşya ile diğer geri kazanılabilir atıklar, atık ilaçlar ve büyük hacimli atıklar mahalli idarelerin oluşturulmuş toplama noktalarına, atık getirme merkezlerine ve/ve ya atık işleme tesislerine teslim edilir.” denilmektedir. Yönetmeliğin 12 Temmuz 2019'da yürürlüğe girmesinden bu yana kamu kurum ve kuruluşları tarafından tüm ülkede yaygınlaşmaya başlayan atık yönetim planı uygulamaya konulmuştur (Anonim, 2019a). AEEE'ler sıfır atık çerçevesinde Avrupa Birliği'nin Atık Çerçeve Direktifi kapsamında oluşturulan atık hiyerarşisine göre toplanarak değerlendirilmektedir. Şekil 1'de gösterilen bu hiyerarşiye göre AEEE'lerin öncelikli olarak oluşmalarının önlenmesi esastır. Ülkemizde son zamanlarda atık yönetimi uygulanırken atık piramidinin en üst basamaklarına doğru tırmanma hedef alınmış ve bunu sağlayabilmek için bütünsel yaklaşım benimsenmiştir. Avrupa Birliğinde hâkim olan "al-yap-tüket-at" lineer ekonomi modeli, yerini döngüsel ekonomi modeline bırakmıştır. Ülkemizde de AEEE'lerin üretimi, toplanması ve bertarafında bu model örnek alınmaktadır (REC, 2016; McMahon ve ark., 2019). AEEE problemi sadece ülkemizde değil Dünya'da da oldukça önemli bir sorun teşkil etmektedir. Birleşmiş Milletler (BM) tarafından 2019 y1lında hazırlanan rapora göre dünyada her yıl 62 milyar dolar değerinde 44 milyon ton e-atık üretildiği ifade edilmektedir (URL-2). Türkiye'de ise yılda ortalama 500 bin ton e-atık oluştuğu ve y1llık olarak bu değerin \%10 arttığı tahmin edilmektedir (URL-3). Bu nedenle e-atık farkındalığını arttırmak amacıyla 2018 yılında 14 Ekim tarihi “Dünya Elektronik Atık Günü” ilan edilmiştir. Her yıl bu tarihte AEEE'lerin toplanması ile ilgili birçok proje ve kampanya düzenlenmekte ve e-atıkların toplanmasına ilişkin bilinç arttırılmaya çalışılmaktadır. 


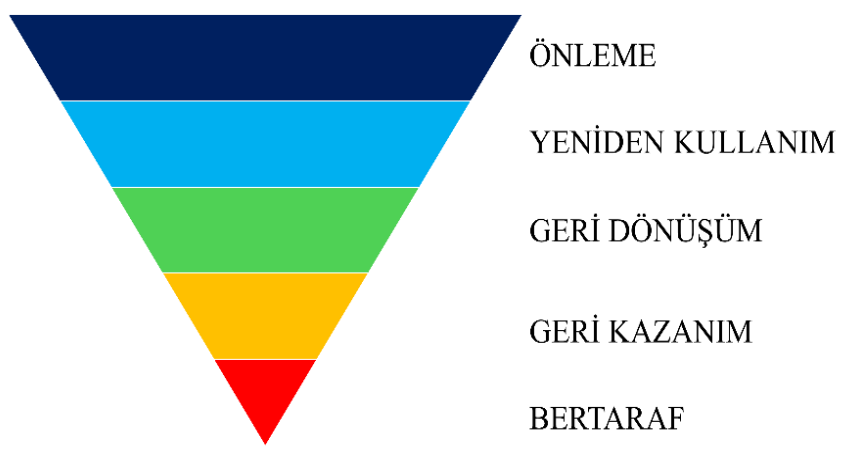

Şekil 1. AB atık hiyerarşisi (REC, 2016).

AEEE yönetiminde belediye sorumlulukları ön plandadır. Bu kapsamda Avrupa'daki ülkelerin çalışmaları incelendiğinde, İsveç, belediyeler ile ortaklaşa e-atık toplama konusunda iyi uygulama örnekleri arasında yer almaktadır (URL-3). Ayrıca Finlandiya'da e-atık toplama konusunda Avrupa'nın örnek ülkelerinin başında gelmektedir. Finlandiya hükümetinin 2000 yılında başlattığ "Cep telefonu firlatma yarışması" ile atık cep telefonları ve bataryalarının uygun yöntemlerle toplanması amaçlanmıştır. Bu yarışma ile AEEE'lere yönelik bilincin artması eğlenceli hale gelmiştir (URL-4). Ülkemizde de sıfır atık kapsamında belediyelerin çalışmaları mevcuttur. Örneğin 2014 yılında İstanbul ili Kadıköy Belediyesi'nin yaptığı bir çalışmada “Anadolu’ya yardım kampanyası” başlığı altında AEEE'ler toplanarak içlerinde yeniden kullanılabilecek EEE'ler uygun hale getirilmiş ve Anadolu'da bulunan çeşitli okullara gönderilmiştir (URL-5). Yine 2016 y1lında sanayinin kalbi olan Kocaeli'de ise, atık toplama merkezlerinin bu şehirde bulunmasından faydalanarak, e-atık toplama kampanyası başlatılmıştır. Kocaeli Büyükşehir Belediyesi bu şekilde 5 yılda 98 ton AEEE'nin geri dönüşümünün sağlandığını belirtmiştir (URL-6). 2018 yılında Çevre ve Şehircilik Bakanlığı ve Türkiye Bilişim Sanayicileri Derneği (TÜBİSAD) işbirliği ile Türkiye Eğitim Gönüllüleri Vakfı'nın (TEGV) geliştirdiği “Atma Bağışla” projesi ile, 50 tondan fazla e-atık geri dönüştürülmüştür (URL-7).

Sıfır atık felsefesiyle AEEE'lerin oluşumunun önlenmesi veya azaltılması için tasarım aşamasında başlayan bir dizi tedbirin alınması gerekmektedir. Yaşam döngüsü analizi (YDA) yaklaşımı ve çevre için tasarım araçları (ÇIT) benimsenerek çevre dostu ürünler, kolay demonte edilebilen tasarımların yapılması, üretim safhasında daha çevre dostu ürünlerin kullanılması, yenilenemeyen kaynak kullanımından kaçınılması, geri dönüştürülen malzemelerin kaynak olarak kullanılması, çabuk bozulan ürünler yerine tamiratı kolay olan sürdürülebilir ürünlerin dizayn edilmesi ve böylece yeniden kullanımının desteklenmesi amaçlanmaktadır (Anonim, 2019a). Yaşam döngüsü analizi ile çevresel etkinin yanı sıra maliyet, malzeme akışı, enerji akışı gibi çok sayıda kıyaslama yapılabilmektedir. E-atıkların yönetiminde başta Avrupa ülkeleri olmak üzere Asya ve 
Kuzey Amerika'da yaşam döngüsü analizi çalışmaları yapılmaktadır (Hong vd., 2015; Xue veXu, 2017). Günümüzde atığın oluşumunu önleyen ya da miktarını azaltan sürdürülebilir temiz ve yeni teknolojilerin kullanımı önem taşımaktadır. Elektrikli ve elektronik eşyaların üretiminde temiz üretim ve endüstriyel simbiyoz teknikleri kullanımı desteklenerek, su ve enerji gibi çokça tüketilen kaynaklarda da büyük ölçüde tasarruf sağlanabilir (Cüce, 2018). Ayrıca yeni yürürlüğe giren Geri Kazanım Katılım Payına İlişkin Yönetmelik kapsamında EEE üretiminde kullanılan ürünlerin bazıları için katılım beyanı yapılmış ve katılım payı tahsil edilmeye başlanmıştır. Bu yaklaşım ile fazla üretimin önüne geçilmesi ve atık oluşumunun engellenmesi hedeflenmektedir (Anonim, 2019b). Ülkemizde uygun bir AEEE yönetimi yapabilmek için öncelikle oluşan atık miktarının bilinmesi ve atıkların kaynağından ayrı toplanması gerekmektedir. Sıfır atık çerçevesinde ise, EEE’lerin üretiminin ve bilinçsiz tüketiminin kontrol altında tutulması ve atık hale gelen EEE'lerin miktarının azaltılması hedeflenmektedir.

Dünyada artış hızı en fazla olan atık türünü AEEE'ler oluşturmaktadır. Resmi kayıtlara göre AEEE toplama, geri kazanım ve geri dönüşüm miktarları diğer atık türlerine göre daha düşüktür. Avrupa'da İtalya (Roma), Almanya (Dresden) ve Sırbistan'1 (Belgrad) kapsayacak şekilde yapılan bir çalışmada sadece hastanede oluşan e-atık miktarı ve yönetimi incelenmiş ve çalışma sonucunda çoğu hastanenin atık yönetim prosedürünün bulunmadığı olanların ise yetersiz olduğu sonucuna varılmıştır (Mannocci ve ark., 2011). Yine 2019 yılında Vietnam'da halkın e-atık toplama konusunda geri dönüşüm bilgisini ölçmek üzere anket çalışması yapılmıştır. Yapılan çalışma sonucunda eatıkların geri dönüşümü konusunda halkın bilinçsiz olduğu sonucuna varılmıştır (Thi Thu Nguyen ve ark., 2018). Malezya'da yapılan bir çalışmada ise evlerde oluşturulan e-atık miktarı iki ayrı model yardımı ile tahmin edilmeye çalışılmıştır. Malezya gibi gelişmekte olan ülkelerin e-atık toplanmasında verilerin kısıtlı olmasından dolayı modellerin böyle ülkeler için kullanılabileceği sonucuna varılmıştır (İsmail ve Hanafiah, 2019). 2016 yılında Bursa'da yapılan gelir düzeyi farklı olan 31 aileyi (100 kişiyi) kapsayan bir anket çalışmasında katılımların ürün kullanımı, ürün değiştirme davranışları ve e-atıklarını nasıl yönettikleri araştırılmıştır. Çalışma sonucunda cep telefonlarının satın alma oranlarının yüksek olduğu ve katılımcıların \%60'ının eski modelleri evde tuttuğu belirtmişlerdir. Çalışma, atık tahminleri yapılırken bu gibi faktörlerinde göz önünde tutulması gerektiğine 1ş1k tutmaktadır (Salihoğlu ve Kahraman, 2016). Bu kapsamda AEEE oluşumu ve yönetimi ile ilgili envanter çalışmalarının arttırılması gerekmektedir.

Samsun ilinde oluşan e-atık miktarı tam olarak bilinmemektedir. Ayrıca e-atıkların toplanması konusunda tüketici dağılımını belirleyen bir çalışmaya rastlanmamıştır. Bu nedenle, gelir dağılımı ve eğitim seviyesi ortalama düzeyde olan İlkadım merkez ilçesinin Bahçelievler mahallesi pilot bölge seçilerek bu bölgede yaşayan mahalle sakinlerinin e-atıklar hakkında bilgi düzeyi, geri kazanım konusundaki tutum, davranış ve alışkanlıklarını tespit etmek amaçlanmıştır. 


\section{Materyal ve Metot}

Samsun ilinde merkez ilçesinde bulunan yaş dağılımı ve eğitim seviyesinin çeşitlilik göstermesi sebebiyle pilot bölge olarak seçilen Bahçelievler Mahallesinde 12 sorudan oluşan anket 100 kişinin katılımıyla 2012 yılında gerçekleştirilmiştir. Anket cevaplarının çeşitliliği için mahalle sosyoekonomik düzeye ve yaş dağılımına göre noktalara ayrılmış ve belirlenen yerlere gidilerek anket çalışması yapılmıştır. Ana kütleden seçilen örnekteki kişiler basit örnekleme yöntemine göre seçilmiştir. Anket bir mahalleye uygulandığı için kişi sayısı 100 kişi olarak seçilmiştir. Anket soruları hazırlanırken ise e-atıkların toplanması, geri kazanımı ve mevzuat ile ilgili bir bilgi düzeyi esas alınmış, literatürde daha önce yapılmış çalışmalardan ve kamu ve özel kuruluşların yürüttüğü çalışmalardan örnekler alarak hazırlanmıştır. Anket yapılmadan önce mahalle sakinlerine anketin amacı ve konusu açıklanmış bunun ardından da anket soruları sorulmaya başlanmıştır. Anket yapılırken seçilen pilot bölgedeki mahalle sakinlerine ilk olarak AEEE'ler hakkında yasal bir yönetmelik tüzük ile ilgili sorular yöneltilerek farkındalıkları ölçülmüştür. Daha sonrasında ise AEEE'lerini nasıl bertaraf ettikleri ile ilgili sorular yönetilerek kullanım sonrası atıklarını değerlendirme yöntemi anlaşılmaya çalışılmıştır. Anketin diğer sorularında ise AEEE'ler ile ilgili bilgi düzeyleri ölçülmesi amaçlanmıştır. Anketin sonraki sorularında ise tüketici alışkanlıklarının ölçülmesi amaçlanmıştır. Anket sonucunda ise mahalle sakinlerinin e-atık hakkındaki bilgi düzeyi, eatıklara karşı tutumu ve e-atıkların toplanması ile ilgili bilgilerin kazandırılması amaçlanmıştır. Anket soruları Tablo 2'de verilmiştir.

Tablo 2. Çalışmada sorulan anket soruları.

\begin{tabular}{l} 
Eğitim durumunuz: \\
() İlköğretim () Ortaöğretim () Lise () Üniversite () Yüksek Lisans \\
\hline Yaşınız: \\
() 20 yaş altı () 20-40 yaş arası () 40 yaş üstü \\
1. Türkiye'de elektrikli ve elektronik ekipman atıklarının yönetimi ile ilgili yasal bir yasa, tüzük, \\
yönetmelik vb. olup olmadığını biliyor musunuz? \\
() Evet () Hayır () Fikrim yok \\
2. Eskimiş, bozulmuş ve kullanmadığınız elektrikli ve elektronik eşyalarınızı nasıl \\
değerlendiriyorsunuz? \\
() Geri dönüşümü yapılıması için aldığım firmaya geri veriyorum. \\
() Geri dönüşümü için bu atıkların geri dönüşümünü yapan firmalara veriyorum. \\
() Ürünün yenisini aldığım halde, bozuk olanını evimde saklıyorum. \\
() Çöpe atıyorum. \\
()Hurdacıya veriyorum. \\
3. Sizce aşağıdaki seçeneklerden hangileri AEEE’ler içinde değerlendirilir? (Gerekli görüyorsanız \\
birden fazla kutucuğu işaretleyebilirsiniz.) \\
() Batarya () Televizyon () Aydınlatma ürünleri (ampul, floresan, vb.) () Diz üstü bilgisayar \\
() Pil \\
4. Aşă̆ı̆dakilerden hangisi elektronik ürünlerin içeriğinde bulunur? (Gerekli görüyorsanız birden \\
fazla kutucuğu işaretleyebilirsiniz.) \\
() Altın () Cam () Bakır () Platin () Arsenik () Plastik
\end{tabular}


5. Buzdolab1, derin dondurucu, klima gibi elektronik aletlerin yapısındaki CFC (Kloro floro karbon) gazlarının insan sağlığı üzerinde olumsuz etkileri olup olmadığı hakkında bilgi sahibi misiniz?

() Evet () Hayır

6. Kullanmadığınız EEE’lerin çöpe atılmamasını belirten herhangi bir uyarı notu veya sembol dikkatinizi çekti mi?

() Evet () Hayır () Bilmiyorum

7. Cep telefonunuzu ne siklıkla değiştiriyorsunuz?

() 6-12 ay () 2-4 y1l () 4-7 y1

8. Kullanılmayan, eskimiş EEE'ler sizce ülkemizde hangi yöntemler ile toplanmaktadır?

() Çöp sahalarına götürülmektedir.

() Diğer atıklardan ayrı toplanmaktadır.

() Yakılmaktadır.

() Hurdacilara verilmektedir.

() Hiçbir farklı işlem uygulamadan günlük çöplerimizle birlikte toplanmaktadır.

() Bilmiyorum.

9. Ülkemizde veya çevrenizde EEE'ler veya parçaları için hazırlanmış olan geri dönüşüm kutuları olsa, atıklarınızı bu kutulara atar miydınız?

() Evet () Hayır

10. Yaşadığınız çevrede EEE’ler veya parçaları için hazırlanmış olan geri dönüşüm kutuları olsa, atıklarınızı bu kutulara atar misınız?

() Evet () Hayır () Bilmiyorum

11. Evinizdeki beyaz eşyalarınızı hangi sıklıkla yeniliyorsunuz?

() 3-5 yil () 5-10 yil () 10-15 yil

12. Beyaz eşyalarınızı yenileme sebebiniz nedir?

() Bozulan ürünü tamir ettirmek yerine yenisini almanın daha kârlı olması

() Daha kullanışlı ürünlerin piyasaya çıkması

() Sahip olduğum ürünün kullanılamaz hale gelmesi

() Teknolojiyi takip etmeyi seviyorum.

\section{Bulgular ve Tartışma}

Çalışma kapsamında öncelikle ankete katılan katılımcıların yaş dağılımları ve eğitim durumları tespit edilmiştir. Ankete katılanların eğitim durumu ve yaş dağılımı Şekil 2'de gösterilmektedir.

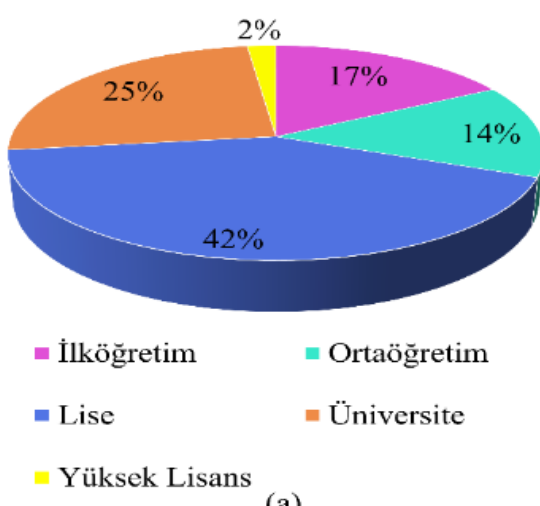

(a)

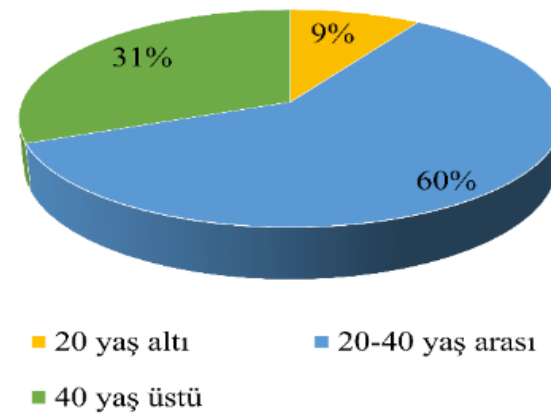

(b)

Şekil 2. Anket uygulanan kişilerin eğitim durumları (a) ve yaş dağılımları (b) 
Şekil 2’ye göre anket uygulanan kişilerin \%60’1 20-40 yaş arasında, \%31'lik kısım ise 40 yaşının üzerinde ve kalan kısım ise 20 yaşın altındadır Katılımcıların \%42'sinin ise eğitim durumunun lise, \%25'lik çoğunluğunun ise üniversite olduğu görülmektedir. Katılımcıların \%2'lik küçük bir kısmının yüksek lisans mezunu olduğu ve kalan \%31'lik kısmın ise ilköğretim ve orta öğretim mezunları oldukları belirlenmiştir.

İlk olarak, katılımcıların Türkiye'de AEEE'lerin yönetimi ile ilgili yasal mevzuat bilgi düzeylerine bakılmıştır. Bu kapsamda AEEE'lerin yönetimi ile ilgili yasal bir tüzük, yönetmelik, yasa vb. olup olmadığı hakkında bilgi sahibi olup olmadıkları sorulmuştur. Cevaplar ise Şekil 3’te verilmiştir.

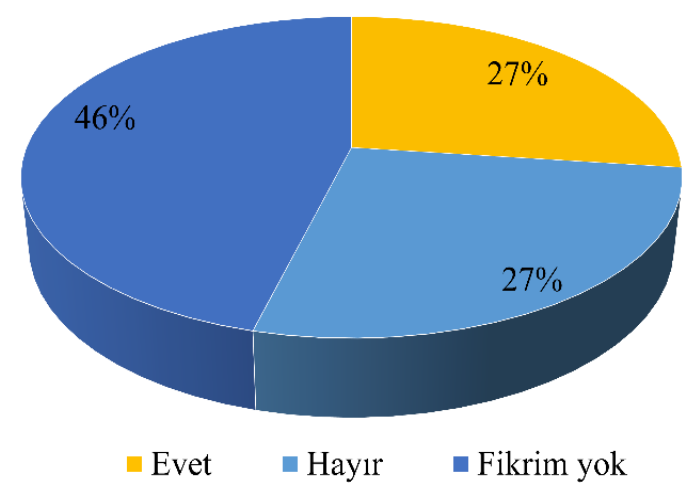

Şekil 3. Katılımcıların Türkiye'de AEEE'lerin yönetimi ile ilgili yasal mevzuat bilgi düzeyleri

Şekil 3 incelendiğinde katılımcıların \%46’lık büyük çoğunluğu “fikrim yok” cevabını verirken \%27'lik kısmı ise "hayır" cevabını vermiştir. Kalan \%27'lik kısım ise "evet” cevabını vermiştir. Katılımcıların \%46'lık kısmının "fikrim yok" cevabını vermesi güncel ve ya taslak halde olan yasal mevzuatlar hakkında bilgi sahibi olmadıklarını ve mahalle halkının yasal mevzuatlara ulaşım konusunda bilinçlendirilmesinin gerekliliğini ortaya koymaktadır.

Anketin ikinci sorusunda ise eskimiş, bozulmuş veya kullanılmayan EEE’lerin değerlendirilme yöntemleri sorulmuştur. Şekil 4'te katılımcıların vermiş oldukları cevapların yüzdesi görülmektedir. 


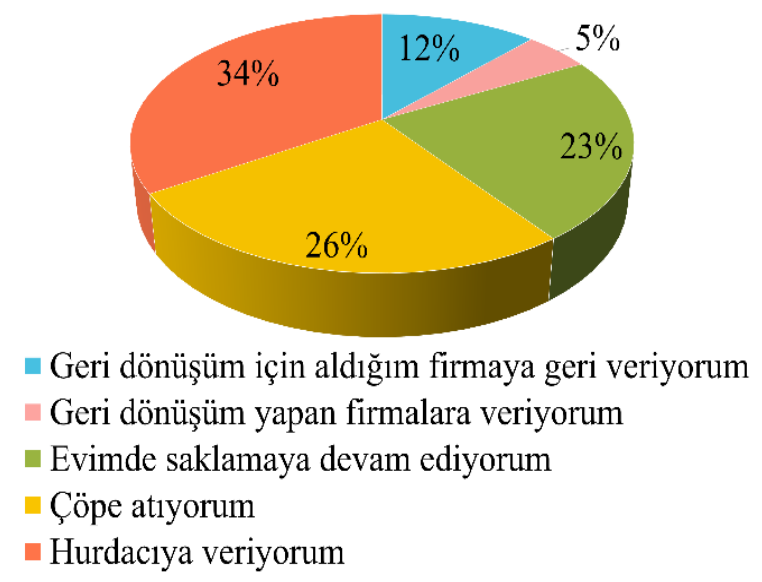

Şekil 4. Katılımcıların eskimiş, bozulmuş ve kullanılmayan EEE’lerini değerlendirime yöntemleri

Şekil 4'e göre katılımcıların \%34'ü eskimiş, bozulmuş veya kullanılmayan EEE'leri hurdacıya para karşılığında verdiklerini, \%26'sı kullanılmaz hale gelen ürünleri çöpe attıklarını, \%23'ü ise ürünün yenisini aldıkları halde bozuk olanını evde saklamaya devam ettiklerini belirtmişlerdir. $\mathrm{Bu}$ oranlar oldukça yüksek çıkmıştır. Anket sırasında katılımcılar, AEEE’lerin değerlendirilmesi ile ilgili bir çalışma yapılırsa ve bilinçlendirilirlerse çalışmaya katılacaklarını söylemişlerdir. $\mathrm{Bu}$ durum mahalle sakinlerinin e-atıkların geri kazanımı ve dönüşümü konusunda bilinçsiz olduğunu, nasıl bir yol izlemeleri gerektiğini bilmediklerini göstermektedir. Atık haline gelen elektronik cihazların nereye götürülmeleri gerektiği konusunda tüketicilerin bilgilendirilmesi gerekmektedir. Katılımcıların \%67'sinin eğitim durumu lise ve üniversitedir. Halka gazete, dergi, broşür, afiş, televizyon ve internet ile gerekli bilgilendirme yapılması ve toplama yeri, zamanı, ne tür atıkların kabul edileceği konusunun açıkça belirtilmesi durumda AEEE'lerin toplanmasında olumlu dönüşlerin alınması mümkündür.

Anketin üçüncü sorusunda AEEE'lerin neler olabileceğine dair bilinç düzeyi araştırılmıştır. Katılımcıların vermiş oldukları cevaplar Şekil 5'te verilmiştir.

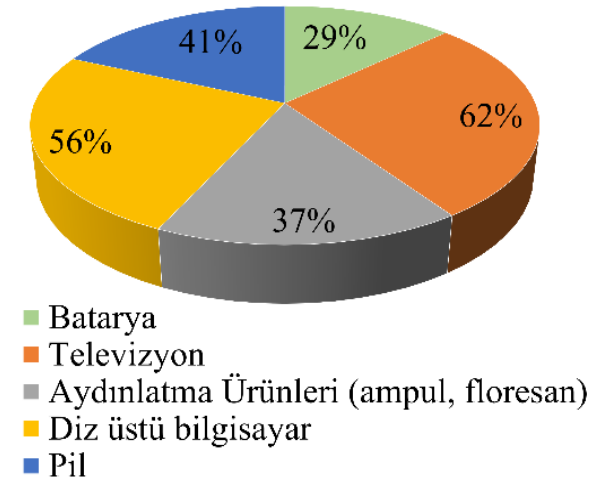

Şekil 5. Katılımcıların AEEE'ler hakkında bilinç düzeyi 
Şekil 5'e bakıldığında en yüksek yüzdelik dilimi \%62 oranında televizyon almıştır. Bir diğer yanıt ise pillerin bir AEEE olarak görülmesi olmuştur. Piller AEEE kapsamında olmamasına rağmen katılımcıların \%41'i pilleri e-atık olarak değerlendirmiştir. Bu yanıt üzerine, Atık Elektrikli ve Elektronik Eşyaların Kontrolü Yönetmeliği Madde 4-1, b bendi Ek-1/A'da tanımlanan kategorilerde yer alan ürünlerin kullanım ömrü dolduğu andaki bütün bileşenlerini, unsurlarını ve ihtiva ettiği sarf malzemelerinin AEEE kapsamında ele alındığını ve demontaj sonrasında pil, akü, batarya gibi tehlikeli madde sınıfına giren tüm parçaların ayrı toplanması gerektiği konusunda mahalle sakinlerine bilgi verildi. Ayrıca katılımcılara pillerin Atık Pil ve Akümülatörlerin Kontrolü Yönetmeliği’ne tabii oldukları ve bu kapsamda pil toplama kutularında ayrı olarak toplanması gerektiği ile ilgili bilgi verilmiştir (Anonim, 2004).

Anketin dördüncü sorusu EEE'lerin içerdiği maddeler ile ilgili mahalle sakinlerinin bilgi seviyesini belirlemek amacıyla sorulmuştur. Seçeneklerde verilen altın, cam, bakır, platin, arsenik ve plastikten hangilerinin AEEE'lerin içerisinde bulunduğu sorulmuştur. Katılımcıların vermiş oldukları cevaplar Şekil 6' da verilmiştir.

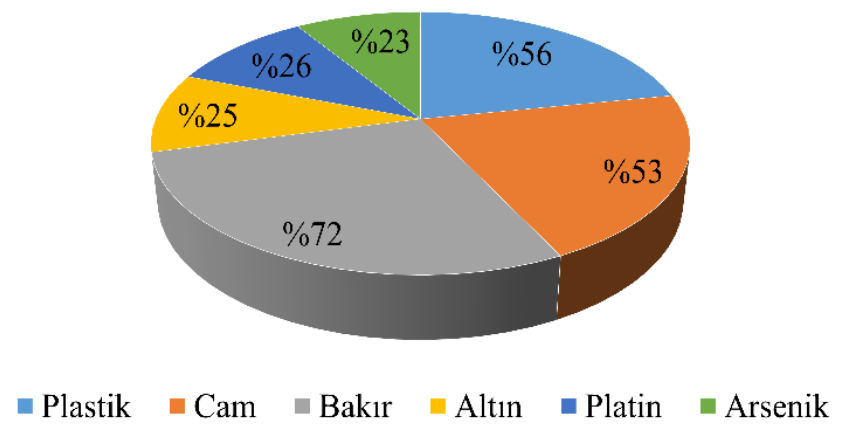

Şekil 6. Elektronik ürünlerin içeriğine ilişkin bilinç düzeyi

Ankete katılanların \%72'si bakırın AEEE'lerin içeriğinde bulunduğunu söylemişlerdir. Katılımcıların çok az bir kısmı altın ve platin seçeneklerini işaretlemişlerdir. Bu durumun; altın ve platinin değerli metaller olduğu için AEEE'lerin içerisinde yer almadığını düşünmelerinden kaynaklandığı anlaşılmaktadır. Sonuç olarak tüketicilerin AEEE'lerin içeriği hakkında yeterli bilgiye sahip olmadıkları kanısına varılmıştır. Halkın, AEEE’lerin içeriğinde değerli materyallerin olduğu ve bu nedenle ekonomik değerinin olduğu konusunda bilgilendirilmesi gerekmektedir. Ayrıca, arsenik ağır metaline verilen yanıt ise \%27'lik kısmı temsil etmektedir. Bu sonuca göre halk, EEE'lerin içerdiği zararlı maddeler hakkında yeterli bilgiye sahip değildir. Anket sırasında katılımcılara, EEE'lerin içerisinde sadece değerli metallerin değil aynı zamanda $\mathrm{Ar}, \mathrm{Pb}$ ve $\mathrm{Cr}$ gibi tehlikeli ağır metallerin ve diğer zararlı bileşiklerin bulunduğu bilgisi de verilmiştir. 
Anketin beşinci sorusunda katılımcılara buzdolabı, klima gibi elektronik aletlerin yapısındaki Kloro floro karbon (CFC) gazlarının insan sağlı̆̆ üzerinde olumsuz etkilere sahip olup olmadığı ile ilgili soru sorulmuştur. Şekil 7'de ankete katılanların vermiş olduğu cevaplar görülmektedir.

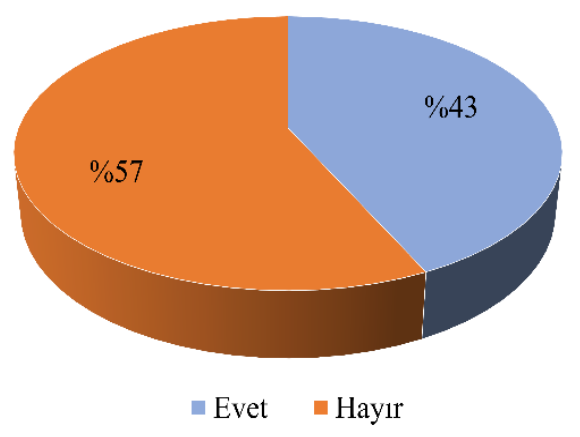

Şekil 7. CFC gazlarının insan sağlı̆̆ üzerinde olumsuz etkisine ilişkin bilinç düzeyi

Verilen cevaplara göre, katılımcıların yarısından azının AEEE’lerin içerisinde sıkça bulunan CFC gazının olası etkileri hakkında bilgi sahibi oldukları tespit edilmiştir. Bu sistemlerde kullanılan CFC gazları; iklim değişikliği, küresel ısınma ve ozon tabakasının incelmesi gibi etkilere neden olmaktadır. Bu nedenle bu tarz e-atıkları nereye götürecekleri konusunda yönlendirilmeye ihtiyaç duydukları belirlenmiştir.

Anketin altıncı sorusunda tüketicilere kullanılan elektrikli ve elektronik ürünlerin üzerinde çöpe atılmamaları gerektiğini belirten herhangi bir uyarı notu veya sembolün dikkatlerini çekip çekmediği sorulmuştur. Katılımcıların vermiş oldukları cevaplar Şekil 8'de verilmiştir.

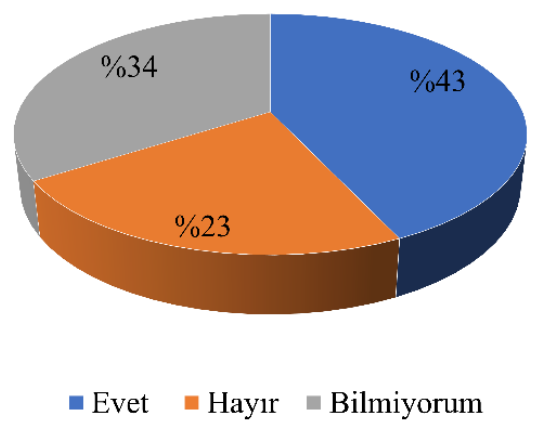

Şekil 8. EEE’lerin çöpe atılmamasını belirten uyarı notu veya sembole ilişkin bilinç düzeyi

Katılımcıların \%43’ü EEE'lerin üzerinde bu ekipmanların direkt olarak çöpe atılmamasını belirten uyarı notu veya sembolü fark etmişlerdir. \%34'lük kısmı ise bu uyarı notu veya sembole ilişkin bilgi sahibi olmadığını belirtmiştir. \%23'lük kısmı ise hayır yanıtı verip böyle bir not veya sembolün olmadığını belirtmiştir. Yönetmeliğin 2012 yılında yürürlüğe konulmasından itibaren EEE 
üreticileri, piyasaya sürülen ürünlerin üzerine Şekil 9'da verilen sembolü yerleştirmekle yükümlüdürler (Anonim, 2019a). Ancak katılımcıların birçoğu elektronik eşyalarını sıklıkla değiştirmediklerini ifade etmişlerdir. Bu nedenle katılımcıların 2012 yılından önce alınan elektronik eşyalarının üzerinde böyle bir ibare bulunmayabileceğinden katılımcıların bu cevabı verdikleri düşünülmektedir.

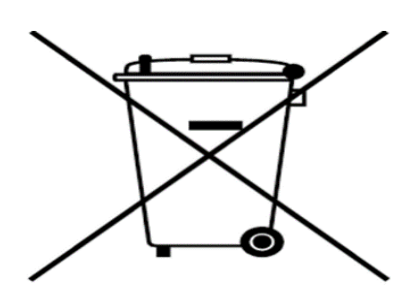

Şekil 9. AEEE işaretlenmesinde kullanılan sembol

Anketin yedinci sorusunda ise katılımcıların cep telefonlarını değiştirme sıklıkları araştırılmıştır. Katılımcıların vermiş olduğu cevaplar Şekil 10’da verilmiştir.

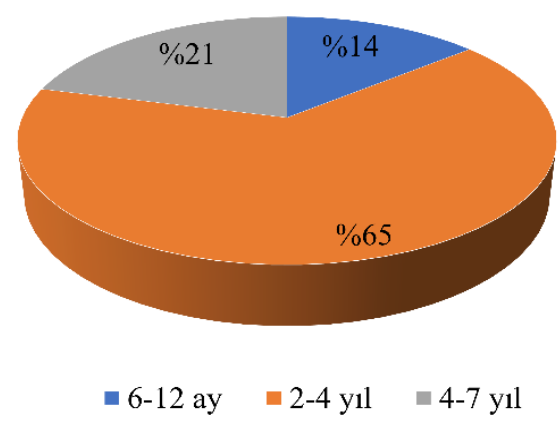

Şekil 10. Katılımcıların cep telefonu değiştirme sıklığı

Katılımcıların verdikleri cevaplar değerlendirildiğinde \%65 oranına sahip büyük çoğunluğunun cep telefonlarını 2-4 yıl arasında yenilediği görülmüştür. Bu durumun gelir düzeyi ve yaş grupları ile ilişkili olduğu düşünülmektedir. Katılımcıların yaşadıkları mahalle merkez ilçede yer almakta olup mahallenin gelir düzeyi düşük değildir. Ayrıca katılımcıların \%60’’nın 20-40 yaş arasında genç kesim olması teknolojik ilerlemeye ayak uydurma çabasında olduklarını göstermektedir.

Anketin sekizinci sorusunda katılımcılara kullanılmayan eskimiş EEE'lerin ülkemizde hangi yöntemlerle toplandığı sorulmuştur. Katılımcıların vermiş olduğu cevaplar Şekil 11'de gösterilmektedir. 


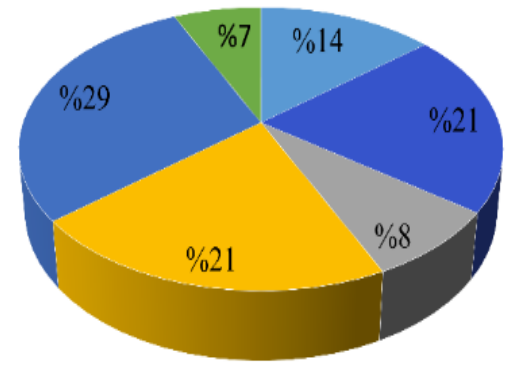

• Çöp sahalarına götürülmektedir.

- Diğer atıklardan ayrı toplanmaktadır.

- Yakılmaktadır.

• Hurdacilara verilmektedir.

- Hiçbir farklı işlem uygulanmadan günlük çöplerimizle birlikte toplanmaktadır.

- Bilmiyorum.

Şekil 11. Katılımcıların kullanılmayan ve eskimiş EEE'lerini bertaraf yöntemleri

Katılımcıların \%29’u kullanılmayan elektrikli ve elektronik ürünlerin hiçbir farklı işlem uygulamadan günlük çöplerle birlikte toplandığını söylemişlerdir. Bu oran AEEE'lerin günlük çöplerle birlikte atıldığını göstermektedir. AEEE'lerin yeniden kullanılması, geri kazanımı ve dönüşümü açısından ayrı toplanması önemlidir. Bu nedenle halkın AEEE'lerin ayrı toplanması konusunda teşvik edilmesi gerekmektedir. Çalışmada \%21'lik kısmı ise diğer atıklardan ayrı toplandığını belirtmişlerdir. Sonuçlara bakıldığında AEEE’lerin toplanması konusunda katılımcıların yeterli bilgiye sahip oldukları düşünülmemektedir. $\mathrm{Bu}$ nedenle AEEE'lerin ekonomik değerinin olduğu halka anlatılmalıdır. Ayrıca yine \%21'lik bir kısmı ise atıkların hurdacılara verildiğini belirtmiştir. $\mathrm{Bu}$ bilgi üzerine katılımcılara e-atıklarını hurdacılara vermeyip ayrı topladıkları eatıklarını toplama kutularına atmaları konusunda bilgi verilmiştir.

Anketin dokuzuncu sorusunda katılımcılara ülkenizde veya çevrenizde EEE’ler veya parçaları için hazırlanmış geri dönüşüm kutularına rastlayıp rastlamadıkları sorulmuştur. Şekil 12'de katılımcıların vermiş oldukları yanıtlar görülmektedir.

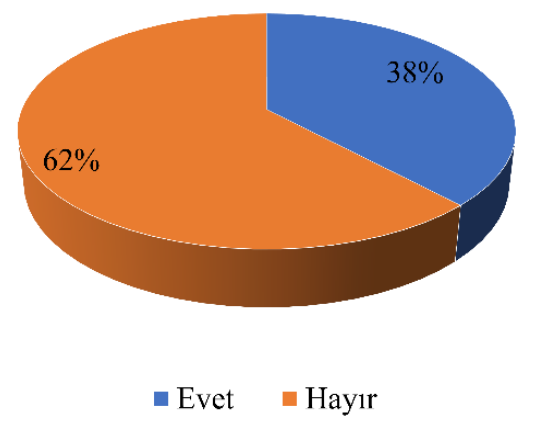

Şekil 12. AEEE’ler için hazırlanmış geri dönüşüm kutularına ilişkin bilinç düzeyi 
Katılımcıların \%62'si çevrelerinde AEEE'ler için hazırlanmış geri dönüşüm kutularına rastlamadıklarını belirtmiştir. Bu oran ülkemizde AEEE'lerin geri kazanımının yaygınlaşmadığını göstermektedir. Ülkemizde sıfır atık çerçevesinde bakanlık, belediyeler ve Türkiye Bilişim Sanayicileri Derneği birçok noktaya atık toplama kutuları yerleştirmişlerdir. Ancak bu sayının daha da arttırılması ve bu konuda bilgilendirme çalışmalarının yapılması gerektiği düşünülmektedir. Katılımcılara Samsun'daki AEEE toplama noktalarının yerleri ile ilgili bilgi verilmiştir ve katılımcılar da oluşacak e-atıklarını bu yerlere götüreceklerini ifade etmişlerdir. AEEE toplama konusunda halkın kolay ulaşabileceği yerlere atık toplama kutularının yerleştirilmesi atıkların toplanması konusunda önemli bir paya sahiptir. Bu şekilde hem çevre kirliliği önlenmiş olacak hem de e-atıklardan ekonomik kazanç elde edilebilecektir.

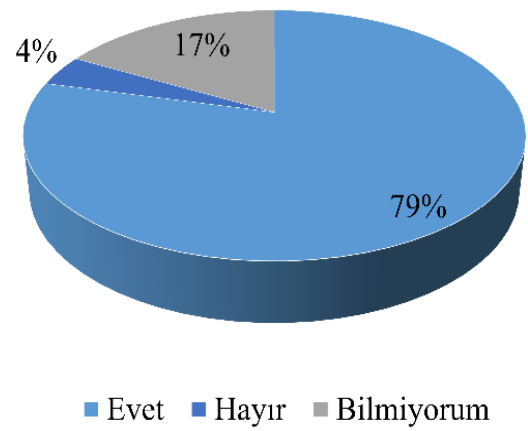

Şekil 13. AEEE’ler için konulacak olan geri dönüşüm ekipmanlarını kullanmaya yatkınlık

Anketin onuncu sorusunda katılımcılara, yaşadığınız çevrede EEE'ler veya parçaları için hazırlanmış olan geri dönüşüm kutuları olsa, atıklarınızı bu kutulara atar mısınız sorusu yöneltilmiştir. Katılımcıların vermiş oldukları cevaplar Şekil 13'te gösterilmektedir.

Katılımcıların \%79'u evet cevabını vermiştir. Bu oran, katılımcıların katkı sağlayacaklarını göstermektedir. Şu an Samsun'da hali hazırda üç adet AEEE toplama noktası ve bir adet AEEE işleme tesisi bulunmaktadır (URL-8). Nüfusu 1.335,716 kişi olan bu büyükşehir için AEEE toplama noktaları yetersizdir. Ancak sıfır atık kapsamında Samsun'da AEEE toplama kutuları tüm belediyelerin politikasına eklenmiş olup en kısa zamanda uygulamaya başlanacaktır (URL-9). AEEE'leri bulunan tüketicilerin rahatlıkla bu yerlere erişebilmeleri esastır. $\mathrm{Bu}$ nedenle toplama noktalarının sıklığının artması hem halkın e-atığa olan bilincini arttıracak hem de daha fazla e-atık toplanmasına olanak sağlayacaktır. Ayrıca \%17'lik kısım “hayır” cevabını vermiş ve \%4'lük kısım ise çekimser kalmıştır. Yaklaşık \%21'lik kısımın ise e-atık toplama konusunda yeterli farkındalığa sahip olmadığı düşünülmektedir.

Anketin on birinci sorusunda katılımcılara beyaz eşyalarını değiştirme sıklıkları sorulmuştur. Şekil 14’te katılımcıların vermiş oldukları cevaplar görülmektedir. 


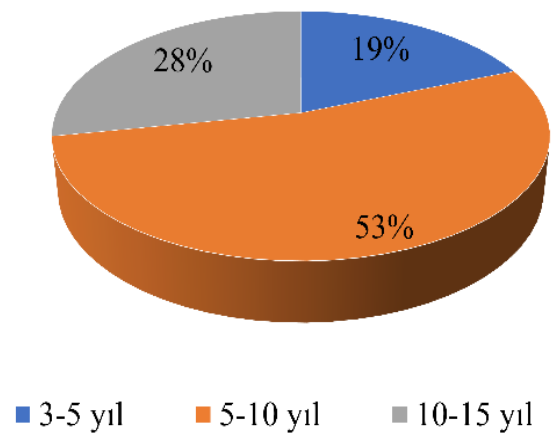

Şekil 14. Kullanılan beyaz eşyaları değiştirme sıklığı

Katılımcıların \%53'lük kısmı beyaz eşyalarını 5-10 yıl içerisinde değiştirdiğini söylemiştir. Katılımcıların \%28'i ise beyaz eşyalarını 10-15 yılda değiştirdiklerini ifade etmişlerdir. Kalan \%19'lık kısım ise 3-5 yıl arasında değiştirdiklerini söylemişlerdir. Ankete katılanların yaş aralığının \%60’1 20-40 yaş arasındaki genç ve orta yaş kesimden oluşmaktadır. Bu durum yorumlandığında katılımcıların beyaz eşyalarının yeni olabileceği ve bozulmadığı sürece değiştirme gereği duymamış olabilecekleri düşünülmektedir. Fakat gelişen teknoloji ile birlikte ürünlerin kullanım kolaylığının artması gibi nedenlerle piyasaya sürülen yeni modelleri alma isteğinin olabileceği düşünülmektedir. Günümüzde üretilen EEE’lerin kullanım ömürleri genellikle eskilere nazaran fazla uzun değildir. Bu nedenle bozulan EEE'lerin tamir ücretinin yeni cihaz alım ücretine yakın olması gibi nedenlerden dolayı da beyaz eşyaların değişim sıkılığında artış olduğu düşünülmektedir.

Anketin son sorusu olan on ikinci soruda katılımcılara beyaz eşyalarını değiştirme sebepleri sorulmuştur. Katılımcıların vermiş oldukları yanıtlar Şekil 15'te verilmiştir.

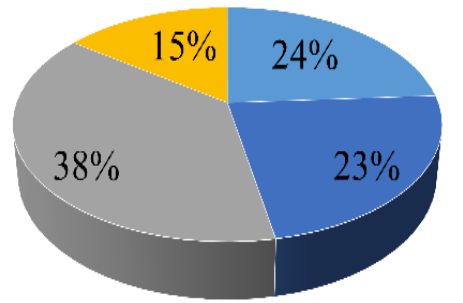

- Bozulan ürünü tamir ettirmek yerine yenisini almanın daha karlı olması.

- Daha kullanışlı ürünlerin piyasaya çıkması.

ఐ Sahip olduğum ürünün kullanılamaz hale gelmesi.

- Teknolojiyi takip etmeyi seviyorum.

Şekil 15. Katılımcıların beyaz eşyalarını değiştirme sebepleri 
Katılımcıların \%38’ı beyaz eşyalarını değiştirme sebebi olarak sahip oldukları ürünlerin kullanılamaz hale geldiğini söylemişlerdir. Katılımcıların \%15'i ise teknolojiyi takip etmeyi sevdikleri için eskimemiş bile olsa beyaz eşyalarını yenilediklerini söylemişlerdir. \%24'lük kesim ise bozulan ürünün tamir edilmesinden ise yenisini satın almanın daha kârlı olduğunu düşünmektedir. Kullanım ömrünü tamamlamadan çöpe atılan e-atıklar hem çevre kirlenmesine neden olmakta hem de fakir bölgelerde yaşayan halkın bunlara erişmesine olanak sağlamamaktadır.

Global e-waste monitör raporuna göre, 2016 yılında Dünya' da toplam 44,7 milyon ton e-atık oluşmuş ve sadece 8,9 milyon tonu (\%20) toplanmış ve geri dönüştürülmüştür (URL-10). Avrupa Komisyonu raporuna göre ise 2017 y1lında Türkiye'de piyasaya sürülen toplam elektrikli ve elektronik eşya miktarı 777 bin tondur ve 2017 yılında 19 bin ton e-atık toplanarak sadece \%3'lük bir geri dönüşüm oranına ulaşabilmiştir (URL-11). Bu verilere göre e-atık tsunamisi tüm dünyaya hızlıca yayılmakta ve dünya üzerindeki rezervi gittikçe azalan hammaddelerin kullanılması e-atıkların yönetimine ilişkin bir diğer boyutu ortaya koymaktadır. Sıfır atık politikası kapsamında gereken önlemlerin alınması ve e-atıkların mevzuata uygun toplanması hedeflenmelidir.

\section{Sonuçlar ve Öneriler}

Hızla gelişen teknolojinin kirli yüzü olan AEEE’ler içerdikleri tehlikeli bileşenler nedeniyle, çevre ve insan sağlığını tehdit etmektedir. AEEE'ler uygun yönetilmediklerinde doğal kaynaklar bozulma veya yok olma tehlikesi ile karşı karşıya kalmaktadır. Uygun yönetildiklerinde ise hem çevreye olan zararlı ve olumsuz etkileri azalmakta hem de içerdikleri değerli metaller geri kazanılarak ekonomiye katkı sağlanmış olmaktadır. Sıfır atık çerçevesinde AEEE’lerin uygun yönetilerek toplanması ve ayrıştırılması ile AEEE'lerin yeniden kullanımı, geri dönüşümü ve geri kazanılması sağlanacaktır. Ayrıca, EEE'lerin çevre dostu olarak tasarlanmasına, piyasa yapısının gelişmesine, teknolojik birikimin ve bilinç düzeyinin arttırılmasına olanak sağlayacaktır.

Çalışma kapsamında AEEE'lerin sıfır atık çerçevesinde geri kazanımı ve geri dönüşümü ile ilgili mahalle sakinlerinin bilinç düzeyi tespit edilmeye çalışılmıştır. Anket sonucunda, katılımcıların AEEE'lerin toplanması, geri kazanımı ve geri dönüşümü hakkında çok fazla bilgiye sahip olmadıkları belirlenmiştir. Ancak katılımcılar, AEEE'lerin yönetimi hakkında bilgilendirildikleri takdirde böyle bir çalışmanın içerisine girebilecekleri kanısına varılmıştır. Bu konuda halkın gazete, dergi, televizyon, internet gibi yayın organları ile bilgilendirilmesi AEEE'lerin kaynağında ayrı toplanması konusunda büyük önem taşımaktadır. Yine anket çalışmalarının bir diğer sonucunda ise katılımcıların \%79 gibi büyük bir kısmının evlerinin yakınlarında AEEE toplama kutularının bulunması durumunda e-atıklarını bu kutulara atmak istediklerini belirtmişlerdir. Ancak yine anket sonuçlarına göre AEEE 
toplama kutularının sayısının yetersiz olduğu tespit edilmiştir. Bu konudaki eksiklik Samsun Büyükşehir belediyesine iletilmiştir.

Çalışma sonucunda yapılabilecek bazı öneriler şu şekildedir:

- Sıfır atık politikası kapsamında kamu, belediyeler ve özel sektörün ortak çalışması ile tüketicilerin AEEE'ler hakkında bilinçlendirilmesi ve AEEE toplama kutularının yaygın hale getirilmesi sonucunda, ülkemizdeki AEEE’lerin geri dönüşüm ve geri kazanım oranlarının zamanla artacağı düşünülmektedir.

- E-atık toplama kutularının yaygınlaşması ile kaynakta ayrışma artar ve bu sayede e-atıkların bünyesinde yer alan altın, bakır, platin gibi atıklar değerlendirilerek ekonomik katkı sağlanabilir.

- Küçük ölçekte yapılan bu çalışmanın sonuçları AEEE'ler konusunda mahalle sakinlerinin tutumu hakkında bilgi sahibi olmamıza olanak sağlayarak örnek teşkil etmektedir. AEEE'ler hakkında çalışma yapılmayan şehirler ve bölgeler, valilik, kaymakamlık, belediye gibi kurumların sosyal medya aracılığ ile kamu spotu oluşturarak halkı e-atıklar konusunda bilinçlendirebilir, yine halka bu tarz anket çalışmaları yaparak anket sonuçlarına göre var olan eksiklik ve olumsuzluklarını düzeltebilirler.

- Çalışma sonucunda belediyeler ile işbirliği yapılarak Samsun ili genelinde, Karadeniz bölgesinde ve hatta ülke genelinde çalışmalar genişletilerek sıfır atık politikasına destek verilebilir.

\section{Yazarların Katkısı}

Esra Ay Sarıyar, anket verilerinin toplanmasında ve yorumlanmasında görev almıştır. Sevde Üstün Odabaşı, makalenin yazılmasında ve verilerin yorumlanmasında görev almıştır. Hanife Büyükgüngör çalışmanın planlanmasında ve yürütülmesinde görev almıştır. Tüm yazarlar makalenin son halini okumuş, düzenlemiş ve onaylamışlardır.

\section{Çıkar Çatışması Beyanı}

Yazarlar arasında herhangi bir çıkar çatışması bulunmamaktadır.

\section{Araştırma ve Yayın Etiği Beyanı}

Yapılan çalışmada araştırma ve yayın etiğine uyulmuştur. 
$\mathrm{Bu}$ çalışma, Ondokuz Mayıs Üniversitesi, Fen Bilimleri Enstitüsü, Çevre Mühendisliği Bölümü, YÖK tez numarası: 324500 olan “Atık elektrikli ve elektronik eşyaların geri kazanımının değerlendirilmesi ve Samsun ilinde seçilen pilot bir bölgede uygulanması” başlıklı yüksek lisans tezinin bir kısmından yapılmıştır.

\section{Kaynaklar}

Anonim, (2011). Directive 2011/65/EU of the European Parliament and of the Council of 8 June 2011 on the Restriction of the Use of Certain Hazardous Substances in Electrical and Electronic Equipment.

Anonim, (2012). Atık Elektrikli ve Elektronik Eşyaların Kontrolü Yönetmeliği, R.G. Tarihi:22.05.2012, R.G. Sayıs1:28300, Çevre ve Şehircilik Bakanlığı, Ankara.

Anonim, (2004). Atık Pil ve Akümülatörlerin Kontrolü Yönetmeliği, R.G. Tarihi: 31.08.2004, R.G. Sayıs1:25569, Çevre ve Şehircilik Bakanlığı, Ankara.

Anonim, (2019a). Sıfır Atık Yönetmeliği, R.G.Tarihi:12.07.2019, R.G. Sayısı:30829, Çevre ve Şehircilik Bakanlı̆̆ 1 , Ankara.

Anonim, (2019b). Geri Kazanım Katılım Payına İlişkin Yönetmelik, R.G. Tarihi:31.12.2019, R.G. Sayısı: 30995 (4. Mükerrer), Çevre ve Şehircilik Bakanlı̆̆ 1 , Ankara.

Ay. E., (2012). Atık Elektrikli ve Elektronik Eşyaların Geri Kazanımının Değerlendirilmesi ve Samsun İlinde Seçilen Pilot Bir Bölgede Uygulanması. Yüksek Lisans Tezi, Ondokuz Mayıs Üniversitesi, Fen Bilimleri Enstitüsü, Samsun.

Ay, E. ve Büyükgüngör, H., (2011, Ekim). Samsun İlinde Atık Elektrikli ve Elektronik Eşyaların Geri Kazanımının ve Yönetiminin Değerlendirilmesi. 9. Ulusal Çevre Mühendisliği Kongresi (s.509-513). Samsun.

Cüce, H., (2018). Endüstriyel Üretimde Döngüsel Çevre Politikaları, Nevşehir Bilim ve Teknoloji Dergisi, 7(2), 111-122.

Çelik, Ç., (2007). Elektrikli ve Elektronik Atıklardan Metal ve Plastik Geri Kazanımının Araştırılması. Yüksek Lisans Tezi, İstanbul Teknik Üniversitesi, Fen Bilimleri Enstitüsü, İstanbul.

Dwivedy, M., ve Mittal, R. K., (2010). Estimation of Future Outflows of E-Waste in India. Waste Management, 30, 483-491.

Gullet, B. K., Linak, W. P., Touati, A., Wasson, S. J., Gatica, S., ve King, C. J., (2007). Characterization of Air Emissions and Residual Ash from Open Burning of Electronic Wastes During Simulated Rudimentary Recycling Operations. Journal of Material Cycles and Waste Management, 9, 69-79.

Hong, J., Shi, W., Wang, Y., Chen, W., ve Li, X., (2015). Life Cycle Assessment of Electronic Waste Treatment, Waste Management, 38, 357-365.

İsmail, H., ve Hanafiah, M. M., (2019). A Preliminary Study on E-Waste Generation from Households in Malaysia, AIP Conf. Proc, 2111, 1-7.

Lambert, A. J. D., ve Gupta, S. M., (2005). Disassembly Modeling for Assembly, Maintenance, Reuse, and Recycling, Boca Raton, CRC Press.

Li, Y., Richardson, J. B., Walker, A. K., ve Yuan, P. C., (2006). TCLP Heavy Metal Leaching of Personal Computer Components, Journal of Environmental Engineering, 132, 497-504.

Keleş, R., Hamamcı, C., ve Çoban A., (2015). Çevre Politikası. Ankara, İmge Kitapevi.

Mannocci, A., Zscheppang, A., La Torre, G., ve Semyonov, L., Chiaradia, G., Denic, L. D., Jankovic, J., Jankovic, S., Boccia, A., Kirch, W., (2011). A Pilot Survey about Waste Management in European hospitals: Focusing on Electrical and Electronic Equipment, Journal of Public Health, 20, 65-69.

McMahon, K., Johnson, M., ve Fitzpatrick, C., (2019). Enabling Preparation for Re-Use of Waste Electrical and Electronic Equipment in Ireland: Lessons from Other EU Member States, Journal of Cleaner Production, 232, 1005-1017.

REC- Bölgesel Çevre Merkezi, (2016). Atık Elektrikli ve Elektronik Eşyaların Kontrolü Yönetmeliği Belediye Uygulama Rehberi, Ankara, Bölgesel Çevre Merkezi.

Salihoğlu, G., ve Kahraman, A. E., (2016). Türkiye'de Elektrikli ve Elektronik Atık Üretimi:Bursa Örneği, Uludağ Üniversitesi Mühendislik Fakültesi Dergisi,21(2), 95-106.

Şentürk, İ., (2019). Elektrikli ve Elektronik Eşya Atıklarının Geri Dönüşümü Konusunda Halkın Bilinç Düzeyinin Ölçülmesi: Sivas İli Örneği. Uluslararası Toplum Araştırmaları Dergisi, 11 (18), 956-978. 
Thi Thu Nguyen, H., Hung, R. J., Lee, H. J., ve Thi Thu Nguyen, H., (2018). Determinants of residents' ewaste recycling behavioral intention: a case study from Vietnam, Sustainability, 11(164),1-24.

URL-1:https://i.unu.edu/media/unu.edu/news/52624/UNU-1stGlobal-E-Waste-Monitor-2014-small.pdf, (Erişim Tarihi:31 Mart 2021).

URL-2:https://www.unenvironment.org/news-and-stories/press-release/un-report-time-seize-opportunitytackle-challenge-e-waste, (Erişim Tarihi:31 Mart 2021).

URL-3:http://www.eagd.org.tr/turkiyede-ve-dunyada-e-atik/, (Erişim Tarihi:20 Mart 2021).

URL-4:https://www.posner.com/geraldposner/2012/08/finland-triumphs-in-mobile-phone 20.html, (Erişim Tarihi:31 Mart 2021).

URL-5: https://issuu.com/marlet corporate publishing/docs/2014fr, (Erişim Tarihi:15 Mart 2021).

URL-6:https://www.kocaeli.bel.tr/tr/main/birimler/atik-yonetimi-sube-mudurlugu/13/news?page=240, (Erişim Tarihi:31 Mart 2021).

URL-7: https://tegv.org/bagis-ve-urunler/atma-bagisla/, (Erişim Tarihi:13 Mart 2021).

URL-8:https://webdosya.csb.gov.tr/db/samsun/icerikler/samsun-il-sifir-atik-yonetim-plani20200918105524.pdf, (Erişim Tarihi: 16 Mayıs 2021).

URL-9:https://data.tuik.gov.tr/Bulten/Index?p=Adrese-Dayali-Nufus-Kayit-Sistemi-Sonuclari-2020-37210 , (Erişim Tarihi: 21 Mayıs 2021).

URL-10:https://rec.org.tr/wp-content/uploads/2020/06/AtiginOtesinde2020.pdf ,(Erişim Tarihi: 19 May1s 2021).

URL-11:https://ec.europa.eu/environment/waste/weee/pdf/Final_Report_Art7 publication.pdf ,(Erişim Tarihi: 23 Mayis 2021).

Widmer, R., Oawald-Krapf, H., Sinha-Khetriwal, D., Schnellmann, M., ve Böni, H., (2005). Global

Perspectives on E-Waste. Environmental Impact Assessment Review, 25, 436-458.

Xue, M.,ve Xu, Z., (2017). Application of Life Cycle Assessment on Electronic Waste Management: A Review, Environmental Management, 59, 693-707. 